\title{
Dinamika Hukum IsLam \\ Dalam Konteks Perubahan Sosial
}

\author{
Ahmad Mubaligh \\ Dosen Fakultas Humaniora dan Budaya Universitas Islam Negeri (UIN) Malang
}

\begin{abstract}
Social alteration is the one of features for society's dynamics life. It is considered as a social law, occurs in life. Social alteration also raises any social problems, which needs arrangement and solving as Islam certainties. Therefore, Islam law be conveyed as law system, based on divine revelation and valid universally, demanded be able to accommodate any social alterations and evils without lost the basic Principles, in other that Islam law can be constant function and feel be needed. However, renewal's efforts of Islam law must be taken place by Islam humanity. In the implementation, movement renewal is done by ijtihad (individual interpretation and judgment).
\end{abstract}

Keywords: Islam low, social alteration

\section{A. Pendahuluan}

Perbincangan mengenai hukum Islam dalam kontek perubahan sosial merupakan suatu kajian yang hingga kini masih sangat menarik dan menjadi fokus perhatian tersendiri bagi umat Islam. Hal ini mengingat, alQur'an sebagai sumber pertama hukum Islam, hanya mengungkapkan prinsip-prinsip hukum secara umum, global, dan implisit, serta dengan jumlah ayat yang sangat terbatas. Sementara pada sisi lain, problematika masyarakat selalu berkembang dan berubah seiring dengan perubahan sosial yang terjadi, yang kesemuanya perlu diatur dan diselesaikan sesuai dengan ketentuan Islam.

Hukum Islam sebagai pedoman bagi kehidupan manusia dituntut untuk mampu mengakomodasi segala bentuk perubahan sosial dan problematika masyarakat yang ditimbulkannya tanpa harus kehilangan prinsip-prinsip dasarnya, sehingga hukum Islam tetap dapat berfungsi dan 
terasa dibutuh-kannya. Sebab, kalau tidak, maka hukum Islam akan kehilangan aktualitasnya, bahkan besar kemungkinan hukum Islam akan mengalami kemandulan fungsi, atau meminjam istilah Abdurrahman Wahid, fosilisasi kepentingan umat (Ahmad Rofiq, 2001: 99).

Dalam rangka mengaktualisasikan hukum Islam dalam konteks perubahan sosial diperlukan adanya upaya-upaya reinterpretasi terhadap ajaranajaran Islam sesuai dengan konteks ruang dan waktu yang mengitarinya. Amiur Nuruddin (1987: 124) mengatakan agama dalam pengertiannya sebagai wahyu Tuhan tidak akan berubah, tetapi pemikiran manusia tentang ajarannya, terutama dalam hubungan dengan penerapannya di tengahtengah masyarakat mungkin berubah. Karena itulah, upaya reinterpretasi tersebut merupakan sunnatullah yang harus dilakukan oleh umat Islam untuk menemukan ketentuan-ketentuan hukum baru sebagai solusi atas segala persoalan yang dihadapinya.

Bertolak dari pemikiran tersebut, dalam tulisan ini penulis berusaha menjelaskan tentang bagaimana dinamika hukum Islam dalam menghadapi perubahan sosial, dengan berpijak pada pembahasan tentang hukum Islam, perubahan sosial: sebuah tantangan bagi hukum Islam, dan pembaharuan hukum Islam.

\section{B. Sekilas tentang Hukum Islam}

Hukum Islam merupakan pedoman dan petunjuk bagi kehidupan manusia dalam menentukan pandangan hidup dan prilakunya, baik secara individu maupun kolektif. Oleh Hasbi Ash-Shiddiqy (1982: 44), hukum Islam didefinisikan dengan koleksi daya upaya para ahli fiqh dalam menerapkan syariat Islam sesuai dengan kebutuhan masyarakat.

Pensyari'atan hukum Islam bertujuan untuk mewujudkan kemaslahatan dan kebahagiaan manusia, baik di dunia maupun di akhirat. Hal ini ditegaskan oleh Ibn al-Qoyyim (lihat Ahmad Zakki Yamani, 1978: 19), bahwa sesungguhnya syariat itu disusun dan didasarkan atas kebijaksanaan dan kemaslahatan umat, baik di dunia dan di akhirat. Syariat itu adil sepenuhnya, dan seluruhnya merupakan rahmat, kemaslahatan bagi manusia serta bijaksana seluruhnya. Maka semua yang keluar dari garis keadilan 
kepada keaniayaan, dari rakhmat kepada kebalikannya, dari kebaikan kepada kerusakan, dan dari kebijaksanaan kepada kesia-siaan, tidaklah termasuk dalam syari'at, walaupun dimasukkan ke dalamnya segala macam dalil.

Kemaslahatan sebagai inti dari tujuan hukum Islam, sebagaimana dikatakan Al-Syatibi (54), adalah karena pada hakekatnya semua kewajiban (taklif) dibuat dalam rangka merealisasikan kemaslahatan hamba. Hukum yang tidak mempunyai tujuan sama seperti taklif ma la yuthaq atau membebankan sesuatu yang tak dapat dilaksanakan. Karena itu, kata Abu Zahrah (1958 : 548), tidak satupun hukum yang disyariatkan baik dalam al-Qur'an maupun al-Sunnah melainkan di dalamnya terdapat kemaslahatan.

Dalam kajian ushul fiqh, tujuan hukum Islam disebut dengan maqasid al-syari'ah, yaitu tujuan atau maksud disyariatkannya hukum Islam, atau oleh sebagian ulama disebut juga dengan asrar al-syari'ah, yaitu rahasiarahasia yang terdapat di balik hukum yang ditetapkan oleh syara', berupa kemaslahatan bagi umat manusia (Abdul Aziz Dahlan, 2001: 1008), misalnya Islam mensyariatkan hukum zina adalah untuk memelihara kehormatan dan keturunan, Islam mensyariatkan hukum pencurian adalah untuk memelihara harta seseorang, Islam mensyariatkan Qisas adalah untuk memelihara jiwa seseorang, dan lain sebagainya.

\section{Perubahan Sosial: Tantangan bagi Hukum Islam}

Perubahan sosial merupakan salah satu ciri bagi dinamika kehidupan masyarakat. Ia dianggap sebagai suatu hukum sosial yang senantiasa terjadi dalam kehidupan. Karena itu, semua masyarakat akan mengalami perubahan secara konstan, dan sebaliknya, tidak satu pun masyarakat yang berhenti pada suatu titik tertentu. Realitas ini sebagaimana digambarkan oleh Ibnu Khaldun (lihat Amiur : 168) bahwa hal ihwal alam dan umat manusia, adat istiadat dan peradaban mereka tidaklah pada satu gerak dan jalan (manhaj) yang tetap, tetapi berubah sesuai dengan pergeseran waktu dan zaman, serta berpindah dari satu kondisi ke kondisi lain, sebagaimana yang terjadi pada manusia, waktu, dan tempat, demikian pula pada dunia dan negara. Sunnah Allah senantiasa berlaku bagi hambanya. Fenomena 
ini nampaknya sulit dibantah, karena ia menyangkut sifat alam yang diciptakan Allah. Realitas alamiah ini, yang di dalamnya tercakup segala aspek dan aktivitas manusia akan selalu mengalami perubahan.

Perubahan sosial secara langsung atau tidak langsung, akan menimbulkan dampak pada berbagai sektor kehidupan, terutama hukum yang berlaku di dalamnya. Hal ini karena, kata Menurut dikutip Yusdani bahwa hukum-sebagairefleksi tata nilai yang diyakini masyarakat sebagai pedoman bagi kehidupan masyarakat- pada dasarnya bukanlah norma statis yang mengutamakan kepastian dan ketertiban, melainkan juga norma-norma yang harus mampu mendinamisasikan pemikiran dan merekayasa prilaku masyarakat dalam mencapai cita-citanya (lihat T. Jabir al-Alwani, 1997: I). Ini berarti, bahwa hukum harus senantiasa berkembang seiring dengan dinamika masyarakat dan mampu mengakomodasi aspirasi atau nilia-nilai yang berkembang di dalamnya.

Dampak perubahan sosial terhadap hukum secara mendasar ditemukan dalam sifat dan watak hukum dan peranannya dalam kehidupan sosial dan tuntutan-tuntutan dalam masyarakat yang didorong oleh berbagai faktor yang bergerak di dalamnya (Sudjono Dirjosisworo, dalam Nasrun Rusli: 156). Dampak ini akan sangat menentukan bagi kelangsungan kehidupan dalam masyarakat. Artinya, apabila hukum berlangsung secara seimbang dengan perubahan sosial, maka hukum akan dapat menjadi solusi bagi berbagai dampak perubahan sosial tersebut. Namun sebaliknya, apabila hukum tidak berkembang secara seimbang atau tertinggal, maka akan terjadi hambatan-hambatan dalam berbagai sektor kehidupan masyarakat, dan bahkan dapat menimbulkan disorganisasi, yaitu memudarnya ketentuanketentuan lama, sementara ketentuan-ketentuan baru belum tersusun. Kondisiseperti ini, dapat pula berlanjut pada terjadinya anomie atau keadaan kacau karena tidak adanya pedoman bagi masyarakat (Nasrun Rusli, 156 157). Dengan demikian, maka keseimbangan antara perkembangan hukum dan perubahan sosial merupakan suatu keharusan, yang tidak dapat ditawar-tawar lagi. Dan dengannya, kehidupan akan berlangsung secara stabil dan normal.

Hukum Islam sebagai salah satu sistem hukum yang bersumber dari wahyu Allah, juga tidak terlepas dari statement-statement di atas. Artinya, 
hukum Islam juga akan dihadapkan pada berbagai persoalan yang ditimbulkan oleh perubahan sosial tersebut. Dalam konteks ini, hukum Islam yang memiliki ciri khas tersendiri, yaitu hukum yang bercorak responsif, dinamis, adaptif, dan fleksibel (lihat Amir Mu'allim dan Yusdani, 1999: XII), tentu harus mampu menghadapi perubahan sosial dengan memberikan ketentuan-ketentuan hukum yang dibutuhkan oleh pemeluknya, sehingga hukum Islam mampu mewujudkan dan memenuhi hajat hidup manusia, serta senantiasa dapat dipedomi dalam berbagai komunikasi dan interaksi sosial.

Bagi hukum Islam, sebenarnya tuntutan tersebut bukanlah sesuatu yang mustahil dilakukan, karena pada dasarnya hukum Islam adalah hukum yang mengalir dan berakar pada budaya masyarakat. Dalam arti, meskipun hukum Islam tergolong hukum yang otonom karena adanya otoritas Tuhan di dalamnya, tetapi implementasinya sangat applicable dan acceptable dengan berbagai budaya lokal (Marzuki Wahid dan Rumadi, 2001: 81).

Amir Mu'allim dan Yusdani mengatakan hukum Islam adalah hukum yang hidup dan berkembang di masyarakat (Amir Mu'allim dan Yusdani, 1999: XII). Hukum Islam bukanlah unifikasi yang baku yang sudah tidak bisa diinterpretasikan, melainkan sebagai kekuatan normatif yang selalu menjadikan, menempatkan, memperlakukan atau mempertimbangkan ke-pentingan masyarakat sebagai substansi dari posisi fleksibilitasnya (flexible-position), selama tidak berorientasi mengorbankan kẹluhuran hukum Islam (Said Agil Husein al-Munawar, 1996: 54-56).

Selain itu, secara sosiologis bahwa hukum Islam adalah suatu pranata sosial yang memiliki dua fungsi. Pertama sebagai social control, bahwa hukum Islam ditempatkan sebagai blue-print (cetak biru) Tuhan, yang selain sebagai kontrol sosial, juga sebagai sosial engineering terhadap keberadaan suatu komunitas masyarakat. Kedua sebagai nilai baru dari perubahan șosial, bahwa hukum Islam lebih merupakan produk sejarah yang dalam batas-batas tertentu diletakkan sebagai justifikasi terhadap tuntutan perubahan sosial, budaya, dan politik (Ahmad Rofiq, 98-99).

Bertolak dari pandangan tersebut, maka sesungguhnya hukum Islam itu memiliki kekuatan yang sangat besar untuk menghadapi perubahan sosial. Ia akan selalu mampu memberikan solusi atas berbagai persoalan 
yang diakibatkan olehnya sebagai wujud dari peranan dan fungsinya dalam kehidupan di masyarakat. Hanya saja, harus disadari bahwa dalam menghadapi perubahan sosial, terkadang kekuatan tersebut belum sepenuh-nya dimanfaatkan secara optimal, sehingga hukum Islam belum mampu berperan dan berfungsi sebagaimana mestinya. Karena itulah, dalam menghadapi perubahan sosial diperlukan adanya sikap-sikap yang harus diperhatikan umat Islam. Dalam hal ini, ada dua sikap yang pernah digunakan sahabat Umar bin Khaththab, yang masih dianggap relevan dan penting untuk digunakan pada masa sekarang. Kedua sikap itu, kata Amir Nuruddin (1987: 132 - 133) adalah:

\section{Beradaptasi dengan tantangan baru secara kreatif}

Dalam menggunakan sikap ini, agaknya dapat dipergunakan teori yang dikemukakan oleh Fazlur Rahman yang berkaitan dengan reaksi masyarakat terhadap perubahan sosial. Dalam teori itu diungkapkan apabila kekuatan-kekuatan baru terjadi di dalam, atau menimpa suatu masyarakat, maka nasib masyarakat itu akan tergantung pada: sampai berapa jauhkah ia sanggup menghadapi tantangan baru itu secara kreatif. Dalam hal ini, umat Islam harus mampu menghadapi kekuatankekuatan baru secara berani dan beradaptasi dengan melakukan asimilasi, absorbsi, dan bila perlu menerimanya tanpa mengorbankan nilai-nilai esensial dan ideal yang dibawah syari'at. Dan harus dapat menghindarkan diri dari sikap-sikap ekstrim, yaitu panik, takut, dan mencari perlindungan khayali ke masa lampaunya, serta menghindarkan diri dari sikap mengorbankan atau mengkompromikan.

Sikap ini pernah digunakan oleh sahabat Umar bin Khaththab dalambeberapa kasus yang diselesaikannya, seperti masalah gelar khalifah. Dalam hal ini, umar melihat bahwa Abu Bakar di sebut khalifah (pengganti) karena ia telah menjalankan tugasnya setelah wafatnya Rasulullah SAW. Sementara, ketika Umar menjalankan tugasnya sebagai pengganti abu Bakar, tentu akan diberi gelar pengganti pengganti Rasulullah. Menurutnya, sebutan itu terlalu panjang. Umar tampaknya tertarik memikirkan itu, karena sebagaimana di ketahuinya negaranegara taklukan mempunyai warisan yang bersifat politis (al-turats alsiyasi), yang menyebut pemimpinnya adalah raja (malik). Namun dalam 
sebuah sumber disebutkan bahwa Umar ragu menggunakan gelar tersebut.

\section{Berorientasi Pada Sejarah Secara Kontekstual}

Sikap ini digunakan untuk menghadapi perubahan-perubahan sosial, dengan cara melihat peristiwa-peristiwa sejarah yang berasal dari Rasulullah SAW dalam konteks sosio-historisnya. Oleh karena itu, interpretasi terhadap teks-teks syari'ah harus dikaitkannya dengan kondisi masyarakat dan kurun waktu dimana teks-teks tersebut diturunkan. Sikap ini pernah digunakan oleh sahabat Umar bin Khaththab dalam beberapa kasus yang diselesaikannya, seperti masalah talak tiga. Dalam hal ini, beliau mengadakan penyesuaian talak tiga yang diucapkan sekaligus menjadi jatuh tiga, dengan situasi dan kondisi umat pada waktunya. Hal ini dapat diasumikan bahwa beliau sebenarnya mempertimbangkan kasus aktual tersebut dengan situasi sosio-historisnya agar jangan bermain-main dengan talak. Pengetatan yang dilakukan oleh Umar adalah semacam sanksi, agar orang-orang tidak seenaknya menjatuhkan talak tiga sekaligus. Pendapat Umar ini didasarkan pada kemaslahatan yang dilihatnya pada waktu itu.

\section{Pembaharuan Hukum Islam}

\section{Gagasan tentang Pembaharuan Hukum Islam}

Pembaharuan (modernisme), sebagaimana dikatakan Harun Nasution (1875 : 11) adalah pikiran-pikiran, aliran-aliràn, gerakan dan usaha untuk mengubah faham-faham, adat istiadat, institusi-institusi lama, disesuaikan dengan suasana baru yang ditimbulkan oleh kemajuan ilmu pengetahuan dan teknologi modern. Sedangkan dalam Islam (baca: hukum Islam), pembaharuan (tajdid) -secara sederhana- dapat diartikan sebagai upaya, baik secara individu maupun kelompok pada kurun dan sistuasi tertentu, untuk mengadakan perubàhan dalam persepsi dan praktek keislaman yang telah mapan (established) kepada pemahaman dan pengalaman baru (Ahmad Rofiq: 97): 
Upaya pembaharuan bertujuan untuk menyesuaikan pahampaham keagamaan Islam (baca: hukum Islam) dengan perkembangan baru yang timbul akibat dari perubahan tersebut, dengan memberikan tatanan yang relevan dengan nilai-nilai kemanusiaan (fithrah), mengubah tatanan lama yang sudah mapan, dan memberikan tatanan baru bagi masyarakat yang dikehendakinya. Hal ini karena, secara real bahwa perubahan dan perkembangan yang terjadi selalu membawa perubahan nilai, sistem, dan berbagai problem, terutama dalam bidang hukum (Ahmad Rofiq: 98). Said Agil Husin al-Munawar (2003: 90) mengatakan modernisasi adalah suatu proses perubahan yang sangat mempengaruhi budaya dan peradaban manusia dan mau tidak mau begulir menelusuri semua ruang kehidupan.

Sedangkan menurut Ali Yafi (1995: 302), tujuan pembaharuan dalam Islam dapat dilihat dari dua sisi, yaitu sisi defensive dan sisi ofensif. Yang pertama untuk memelihara dan mempertahankan kemurnian ajaran (Islam), dan kedua untuk memberi ruang, nilai-nilai dasar moral keagamaan, patokan-patokan norma keagamaan, tata pergaulan dalam kehidupan. Dengandemikian, secara umum upaya pembaharuan hukum Islam dimaksudkan agar hukum Islam mampu mewujudkan dan memenuhi hajat hidup manusia, serta senantiasa dapat dipedomi dalam berbagai komunikasi dan interaksi sosial.

Kemudian dalam melakukan pembaharuan, menurut Sjechul Hadi Permono (2004 : 6-7), ada tiga prinsip pokok yang harus diperhatikan oleh seorang mujtahid. Ketiga prinsip pokok adalah al-ibanah (liberation), al i'adah (reformation), dan al-Ihya' (modemization).

\section{Al-Ibanah (liberation)}

Proses berfikir yang digunakan dalam memecahkan persoalan hukum harus lebih bersifat pembebasan dari pada ta'ashub madzhab (fanatisme madzhab). Artinya, seorang mujtahid harus secara terbuka dan bebas dalam memilih dan menerapkan pendapat-pendapat para ulama dari madzhab manapun, yang dianggap relevan dengan persoalan hukum yang sedang dipecahkannya. Dan sebaliknya, seorang mujtahid harus mampu melepaskan diri dari sikap keterkungkungan dan fanatisme terhadap madzhab tertentu. Hal 
ini dimaksudkan agar produk hukum yang dihasilkannya dapat diperoleh secara obyektif dan universal, tanpa adanya pengaruh apapun di dalamnya.

\section{Al-I'adah (reformation)}

Upaya pembaharuan dilakukan dengan cara kembali pada Al-Qur'an dan al-hadits dengan berbagai metode dan proses penggalian hukum yang berdasarkan pada ilmu pengetahuan yang sudah diuji kebenarannya oleh para ahlinya, sebagaimana dikaji dalam ilmu ushul figh. Hal ini karena, al-Qur'an dan al-hadits merupakan sumber hukum Islam. Keduanya menjadi rujukan bagi seorang mujtahid dalam menggali hukum Islam. Al-Qur'an berfungsi sebagai dalil pokok hukum Islam, yang harus dinomorsatukan oleh umat Islam dalam menggali dan menemukan hukum Islam. Dari ayatayat al-Qur'an, ditemukan dasar-dasar hukum sebagai petunjuk dan bimbingan dalam memecahkan persoalan yang dihadapi oleh umat Islam.

Sementara al-hadits merupakan sumber hukum Islam kedua, setelah al-Qur'an, sebagaimana yang disepakati oleh para ulama. Ia berfungsi sebagai berikut: (1) Al-Hadits memperkuat apa yang telah ditetapkan dalam al-Qur'an. (2) Al-Hadits berfungsi sebagai bayan atau memberi-kan penjelasan atau perincian terhadap apa yang telah digariskan dalam al-Qur'an. (3) Al-Hadits menetapkan hukum yang belum diatur dalam al-Qur'an.

Ini berarti bahwa seorang mujtahid dalam menggali hukum Islam, di samping menjadikan metode dan proses penggalian hukum yang dirumuskan oleh para ulama terdahulu sebagai alat dan sarana di dalamnya, ia juga harus selalu kembali atau berpedoman pada al-Qur'an dan al-hadits.

\section{Al-Ihya' (modernization)}

Upaya pembaharuan harus menyesuaikan dengan pergeseran kemaslahatan yang ditimbulkan perubahan sosial yang terjadi. Karena, kata Abdul Wahab Afif (lihat Amir Mu'allim dan Yusdani: 37) bahwa kemaslahatan sebagai tujuan syara' tidaklah constant, 
permanent, dan stabil, tetapi ia bersifat dinamis dan fleksibel, dalam arti bahwa pertimbangan kemaslahatan itu sejalan dengan perkembangan zaman. Konsekuensinya, bisa jadi yang dianggap kemaslahatan pada waktu lalu, belum tentu dianggap maslahat pada masa sekarang, dan begitu pula sebaliknya. Kemaslahatan yang dimaksud di sini adalah kemaslahatan-kemaslahatan yang menjadi tujuan syara' (maqasid al-tasyri'), yang meliputi lima unsur pokok dalam kehidupan manusia, yaitu agama, jiwa, akal, keturunan, dan harta.

Dengan tiga prinsip tersebut, diharapkan bahwa upaya pembaharuan hukum Islam yang dilakukan dapat mencapai tujuan sebagaimana disebutkan di atas secara optimal. Di samping itu, dapat juga mengurangi, bahkan kalau bisa menghilangkan frekwensi perbedaan di kalangan umat Islam karena faktor-faktor tertentu seperti yang terjadi selama ini, terutama faktor fanatisme madzhab (ta'ashub al-madzhab).

\section{Ijtihad: Sarana Pembaharuan Hukum Islam}

Dalam kajian ushul figh, ijtihad merupakan suatu metode yang digunakan untuk menyelesaikan persoalan-persoalan hukum, baik yang ada nashnya maupun tidak ada nashnya. Menurut ushuliyyin, ijtihad dipahami sebagai upaya berpikir secara optimal dan sungguh-sungguh dalam menggali hukum Islam dari sumbernya, untuk memperoleh jawaban terhadap permaslahan hukum yang timbul di masyarakat (Musa Thiwani dalam Nasrun Rusli,, 1999 : x). Ijtihad itu dimaksudkan untuk mengembangkan hukum Allah, agar tetap lestari dan berkembang sepanjang masa serta dapat diterapkan di segala ruang dan waktu.

Adadua faktor utama yang menuntut upaya pembaharuan hukum Islam melalui ijtihad. Pertama, adanya nash-nash yang bersifat zhanni. Dalam hal ini, kegiatan ijtihad lebih dikhususkan pada upaya memahami makna-makna yang dimaksud oleh nash.. Kedua, Munculnya berbagai persoalan baru, yang senantiasa menuntut adanya jawaban-jawaban dalam ketentuan hukum Islam. Dalam hal ini, kegiatan ijtihad lebih difokuskan pada penggalian hukum Islam melalui ijtihad bi al-ra'yi, yang dilakukan dengan menggunakan beberapa metode ijtihad yang telah digariskan atau ditetapkan oleh oleh ulama salaf . 
Berdasarkan pada dua faktor tersebut, maka ijithad merupakan suatu proses penemuan hukum yang senantiasa harus dilakukan seiring dengan pergeseran ruang dan waktu. Hal ini karena, ketentuan hukum yang dihasilkan melalui ijtihad, baik dalam faktor pertama maupun kedua, sama-sama bersifat zhanni (masih dapat berubah). Dan ini tentunya dapat memungkinkan bahwa produk ijtihad yang telah dihasilkan tidak lagi relevan dengan kondisi sosial yang ada. Hal ini sebagaimana dibuktikan oleh sejarah, bahwa ijtihad telah dilakukan oleh para mujtahid sejak masa awal pertumbuhan Islam hingga masa sekarang dalam rangka menemukan ketentuan hukum suatu persoalan yang dihadapinya.

Pada masa Rasulullah SAW, banyak sahabat Nabi yang telah melakukan ijtihad tentang berbagai persoalan, baik ketika mereka berada di samping Rasulullah, ataupun ketika mereka berjauhan dengan beliau. Terhadap produk ijtihad sahabat yang beliau ketahui secara langsung, ataupun melalui perantara sahabat yang lain, beliau senantiasa memberikan sikap dan kalau perlu memberikan keputusan; ada yang beliau setujui dan ada pula yang beliau betulkan. Di samping itu, dalam tindakan praktis beliau memberikan kesempatan kepada para sahabat untuk mengemukakan pendapat, terutama dalam persoalan-persoalan yang membutuhkan pemecahan secepatnya. Bahkan, beliau pernah memberikan kesempatan kepada para sahabat untuk menggali hukum dalam masalah yang dihadapinya, seperti yang diberikan beliau pada sahabat Mu'azd bin Jabal. Dengan peluang ijtihad yang begitu besar, maka semangat ijtihad tumbuh subur di kalangan sahabat; sehingga tidak mengherankan kalau ada beberapa sahabat yang tercatat dalam sejarah sebagai seorang mujtahid (Amiur Nuruddin: $x$ ).

Setelah Rasulullah wafat, kebutuhan akan ijtihad semakin meningkat. Menurut Iskandar Usman (1994: 162) hal ini disebabkan oleh dua hal. Pertama, pada masa Rasulullah SAW, wahyu sebagai sumber hukum Islam masih turun, dan selalu memberikan solusi atas persoalanpersoalan yang terjadi. Sedangkan setelah beliau wafat, wahyu sudah tidak pernah lagi turun, sehingga tidak secara otomatis persoalan-persaolan yang terjadi mendapat solusinya. Di samping itu, berbagai persoalan dapat dikembalikan dan dikonsultasikan kepada Rasulullah 
SAW, tetapi setelah itu keadaannya menjadi lain. Semua persoalan menjadi tanggung jawab bagi umat yang ditinggalkan untuk mencari solusinya. Kedua, persoalan-persoalan yang muncul pada masa Rasulullah SAW tidak sebanyak persoalan yang muncul sesudahnya. Masa Rasulullah SAW, wilayah Islam masih kecil, umat Islam belum banyak berinteraksi dengan umat-umat lain. Namun masa sesudahnya, wilayah Islam bertambah luas dan interaksi dengan umat-umat lain sering dilakukan. Karena itu, dengan segala upaya dan kesungguhan, para sahabat berijtihad untuk menemukan solusi atas persoalan-persoalan yang dihadapinya dengan mengambil inspirasi dan menangkap pesan-pesan universal dalam al-Qur'an dan al-hadits.

Setelah masa sahabat, ijtihad dilanjutkan oleh para generasi berikutnya. Banyak cendekiawan dan tokoh fikih dari tabi in dan tabiit altabi'in yang muncul menjelang berakhirnya masa sahabat. Masa ini disebut dengan fase pembinaan dan pembukuan figh Islam, yang berlangsung selama 250 tahun, yaitu sejak akhir abad pertama hijriyah sampai paroh pertama abad keempat hijriyah. Pada masa ini hukum Islam mencapai puncak kejayaannya bersamaan dengan kemajuan Islam di berbagai bidang. Dan masa ini disebut sebagai periode ijtihan dan keemasan hukum Islam. Pada masa ini, terdapat beberapa hal yang menonjol dalam bidang fiqh, antara lain munculnya para imam mujtahid yang memiliki metode ijtihad yang mandiri, yang dapat digunakannya untuk berijtihad secara bebas. Para imam tersebut kemudian mendirikan madzhab-madzhab fiqh yang hingga sekarang masih berkembang luas dan memiliki banyak pengikut berbagai negara (Nasrun Rusli: 7).

Di samping itu, pada masa ini para mujtahid tidak hanya berijtihad untuk menggali hukum dari sumber-sumbernya, tetapi juga mengangkat sejumlah peristilahan fiqh, yang mengukuhkan fiqh sebagai ilmu yang mandiri. Upaya lain yang menonjol adalah dibukukannya karya ashul figh yang pertama oleh al-Syafi'i, yang berjudul al-Risalah (Nasrun Rusli: 7).

Dalam perkembangan selanjutnya, ijtihad dilakukan oleh umat Islam secara terus menerus hingga sekarang. Memang, dalam catatan sejarah, bahwa pada abad $4 \mathrm{H}$ semangat ijtihad pernah melemah, 
bahkan sampai muncul semboyan bahwa pintu ijtihad telah tertutup, sehingga pemikiran Islam mengalami kemandekan, baik dalam ajaran maupun kebudayaan Islam. Akibatnya, umat Islam mengalami kemunduran dalam berbagai bidang, sedang orang Eropa yang mengambil ruh ijtihad mengalami kemajuan pesat. Tapi kemudian, pada akhir abad ke $12 \mathrm{H}$, ketika kebudayaan Eropa yang para ulama dan tokoh Islam menyadari bahwa untuk mengatasi kemunduran umat Islam harus dilakukan dengan cara membuka kembali pintu ijtihad yang dinyatakan sudah tertutup. Tahtawi-seorang pemimpin pembaharu yang muncul pada saat itu- mengatakan bahwa ijtihad perlu diadakan untuk menghadapi problem-problem yang timbul di zaman modern (lihat Harun Nasution: 113-114). Dari sinilah, upaya ijtihad mulai dihidupkan lagi dan berkembang secara kontinyu hingga sekarang ini.

Bertolak dari uraian di atas, jelaslah bahwa ijtihad sebagai sarana pembaharuan hukum Islam merupakan unsur terpenting dalam ajaran Islam. Ia dianggap sebagai kunci bagi dinamika ajaran Islam, termasuk hukumnya. Bahkan, menurut Wahbah Zuhaily (2001: 1115) bahwa ijtihad adalah nafasnya hukum Islam. Melalui ijtihad, ajaran-ajaran Islam ber-kembang pesat pada masa keemasannya. Dan melalui ijtihad pula, persoalan-persoalan yang tidak ada ketentuannya dalam $\mathrm{Al}$-Qur'an dan Al-Hadits dipecahkan oleh para ulama. Karena itu, kalau ijtihad terhenti, maka hukum Islampun terhenti perkembangannya, dan akan terus tertinggal oleh dinamika kemajuan masyarakat.

\section{E. Penutup}

Dari uraian di atas dapat diambil beberapa kesimpulan sebagai berikut:

1. Perubahan sosial merupakan ciri bagi dinamika kehidupan yang senantiasa menimbulkan persoalan-persoalan yang harus dijawab dan diselesaikan oleh hukum Islam.

2. Hukum Islam sebagai pedoman hidup manusia berlaku secara universal. Ia memiliki ciri khas tersendiri, yaitu hukum yang bercorak responsif, dinamis, adaptif, dan fleksibel. Untuk itu, hukum Islam memiliki kekuatan besar untuk menghadapi perubahan sosial dan berbagai persoalan yang diakibatkannya. 
3. Dalam menghadapi perubahan sosial, maka pembaharuan hukum Islam merupakan langkah yang harus dilakukan oleh umat Islam. Pembaharuan ini dilakukan dengan menggunakan ijtihad sebagai metode yang digunakan untuk menyelesaikan persoalan-persoalan hukum, baik yang ada nashnya maupun tidak ada nashnya.

\section{Daftar Pustaka}

Abdul Aziz Dahlan, Ensiklopedi Hukum Islam, Jakarta, PT. Ichtiar Baru Van Hoeve, 2001.

Ahmad Rofiq, Pembaharuan Hukum Islam di Indonesia, Yogyakarta, Gama Media, Cet. Pertama, 2001.

Ahmad Zakki Yamani, Syari'at Islam yang Kekal dan Persoalan Masa Kini, Alih Bahasa: K.M.S. Agustjik, Jakarta, PT. Intermasa, cet. Ke 2, 1978. Ali Yafi, dalam Tim Penulis, Kontektusali Ajaran Islam, Jakarta, Temprint, 1995, cet. I, hal. 302.

Al-Syatibi, al-Muwafaqat fi al-ushul al-Syari'ah, selanjutnya disebut alMuwafaqat, Kairo, Musthafa Muhammad, Juz I.

Amir Mu'allim dan Yusdani, Konfigurasi Pemikiran Hukum Islam, Yogyakarta, UII Press, Cet. Kedua, 1999.

Amiur Nuruddin, Ijtihad Umar bin Khaththab: Studi tentang Perubahan Hukum dalam Islam, jakarta, Rajawali Press, 1987.

Harun Nasution, dalam Tim Penulis, Ijtihad dalam Sorotan, Bandung, Penerbit Mizan: Khazanah Ilmu-Ilmu Islam, Cet. Ke 4, 1996.

—_, Pembaharuan dalam Islam, Jakarta, Bulan Bintang, 1987.

Iskandar Usman, Istihsan dan Pembaharuan Hukum Islam, Jakarta, PT. Raja Grafindo Persada, 1994.

Marzuki Wahid dan Rumadi, Fiqh Madzhab Negara: Kritik atas Politik Hukum di Indonesia, Yogyakarta, LKiS, Cet. I, 2001.

Muhammad Abu Zahrah, Ushul al-Fiqh, Mesir, Dar al-Fikr al-Arabi, 1958.

Nasrun Rusli, Konsep Ijtihad al-Syaukani: Relevansinya bagi Pembaharuan Hukum Islam di Indonesia, Jakarta, PT. Logos Wacana Ilmu, Cet. I, 1999, hal. 155. 
Said Agil Husein al-Munawar, Perkembangan Ilmu Pengetahuan dan Teknologi Serta Rekayasa Teknik Genetika Dalam Perspektif Hukum Islam, Tarjikh, edisi ke I, Des. 1996.

Sjechul Hadi Permono, Pembaharuan Hukum Islam di Indonesia: Pembaharuan Materi Hukum Pidana Islam, Makalah disampaikan dalam Seminar di IAII Sukorejo Situbondo, 2004. 